\title{
Parenting styles and coping strategies among patients with early detected and treated congenital hypothyroidism
}

\author{
María L. Pardo Campos, M.D. ${ }^{a}$, Mariel Musso, M.D. ${ }^{b}$, Ana Keselman, M.D. ${ }^{c}$, Laura Gruñeiro, M.D. ${ }^{c}$, \\ Ignacio Bergadá, M.D. ${ }^{c}$ and Ana Chiesa, M.D.c
}

\begin{abstract}
Congenital hypothyroidism $(\mathrm{CH})$, as any chronic disease, has an impact on the parent-child relationship and on the child's resources to cope with conflicting situations.

Objectives. To describe parenting styles according to the perception of children with $\mathrm{CH}$ and their coping strategies. Population and methods. Children aged 9-10 years who had $\mathrm{CH}$ detected by newborn screening and had received adequate treatment and a group without $\mathrm{CH}$ (control group). The Argentine Coping Questionnaire, the Argentine Scale for the Perception of Parent Relations, and the comprehension subtest of the Wechsler Intelligence Scale for Children III (WISC III) were used. Results were compared using a multivariate analysis of variance (MANOVA).

Results. Sixty children with $\mathrm{CH}$ were included; they perceived that their mothers exercised a strict control and that their fathers showed more acceptance. They sought more support and became paralyzed more often in conflicting situations than the 60 children without $\mathrm{CH}$.

Conclusion. These findings may be associated with a higher level of dependence. They should be taken into consideration in $\mathrm{CH}$ care.

Key words: congenital hypothyroidism, chronic disease, parenting styles, coping strategies.
\end{abstract}

http:/ / dx.doi.org/10.5546/aap.2018.eng.142

To cite: Pardo Campo ML, Musso M, Keselman A, et al. Parenting styles and coping strategies among patients with early detected and treated congenital hypothyroidism. Arch Argent Pediatr 2018;116(2):142146.

a. Universidad Católica Argentina, School of Psychology and Educational Psychology, Childhood Endocrinology Foundation (Fundación de Endocrinología Infantil).

b. Interdisciplinary Center for Research in Mathematical and Experimental Psychology (Centro Interdisciplinario de Investigaciones en Psicología Matemática y Experimental, CIIPME) “Dr. Horacio J. A. Rimoldi" - National Scientific and Technical Research Council (Consejo Nacional de Investigaciones Científicas y Técnicas, CONICET); Universidad Argentina de la Empresa.

c. Hospital de Niños Ricardo Gutiérrez; Childhood Endocrinology Foundation (Fundación de Endocrinología Infantil).

E-mail address:

María L. Pardo Campos, M.D.: mlpardocampos@gmail.com

Funding: None.

Conflict of interest: None.

Received: 12-22-2016

Accepted: 9-9-2017

\section{INTRODUCTION}

Primary congenital hypothyroidism $(\mathrm{CH})$ is a chronic disease that, if diagnosed early and treated in an adequate manner, allows children to grow and develop normally.

According to the World Health Organization (WHO), ${ }^{1}$ a chronic disorder affects the vital development of an individual living in a social setting with an alteration for more than six months. These include psychological and/or social conditions.

A chronic disorder such as $\mathrm{CH}$ may affect the lives of patients and their families. For this reason, children and their families should receive support. ${ }^{2,3}$

Coping strategies are an individual's resources to deal with stressing situations that require a cognitive and / or emotional effort. ${ }^{4,5}$ The way an individual copes with situations depends on the available resources, the limitations of the setting where such resources are used, and his / her ability to implement such resources in dealing with different demands of the environment.-8

The parents of a chronically-ill child use coping strategies that may also influence their child's own strategies. Therefore, it has been reported that chronically-ill children have a lower level of autonomy to develop strategies that will allow them to solve the situations of daily living. ${ }^{9}$

The objective of this study was to characterize parenting styles according to the perception of patients with $\mathrm{CH}$ and their coping strategies.

\section{POPULATION AND METHODS}

This was a descriptive, comparative study with an ex post facto, cross-sectional, and prospective design. Children with $\mathrm{CH}$ were recruited among 200 children seen at the Department of Endocrinology of Hospital de Niños Ricardo Gutiérrez of the Autonomous City of Buenos Aires. An intentional sample of 120 children aged 9 and 10 years was selected.

The inclusion criteria were the following: a) an early diagnosis of $\mathrm{CH}$ (in the first 30 days of life), b) having received an early and adequate treatment since the time of detection, c) receiving 
follow-up and adequately complying with medical and biochemical controls in a regular manner, d) not having a concurrent chronic disease, e) attending public or private single shift schools located in the Autonomous City of Buenos Aires or the province of Buenos Aires and a minimum parental level of education equal to complete secondary education. Both groups made up a non-probability accidental sample. The same cohort participated in the study that allowed to establish the cognitive characterization of children with $\mathrm{CH} .{ }^{10}$

The control group (CG) was recruited from public or private schools located in the Autonomous City of Buenos Aires or the province of Buenos Aires considering the inclusion criteria. School authorities were asked for permission in advance, and parents gave their consent.

The sample was selected in 2010, and data were collected between 2010 and 2011.

\section{Instruments}

All children were assessed using the Argentine Scale for the Perception of Parent Relations for children aged 8 to 12 years, the Argentine Coping Questionnaire for children aged 8 to 12 years, ${ }^{6-8}$ and the comprehension subtest of the Wechsler Intelligence Scale for Children III (WISC III). The latter assessed the comprehension of strategies to solve the situations of daily living that implied a practical social judgment.

The scales and the subtest were administered during an individual outpatient interview inside the office. Individual results were delivered in written during a feedback interview during which the relevant guidelines were provided.

The Research and Teaching Committee and Ethics Committee of Hospital de Niños Ricardo Gutiérrez approved the study, and a written informed consent for study participation was obtained from the parents of studied children.

\section{Statistical analysis}

The sample size of children with $\mathrm{CH}$ to be studied was estimated at 60 children (level of confidence: $95 \%$; absolute accuracy: $5 \%$ on both sides), according to Sample size determination in health studies, by S. K. Lwanga (WHO, Geneva, 1991).

The differences in the perception of parent relations and coping strategies between groups were analyzed using a multivariate analysis of variance (MANOVA), and the differences in the WISC III subtest (comprehension) were studied using Student's t test for independent samples; a $p$ value $<0.05$ was considered significant.

In addition, the effect size was analyzed for all results using the partial Eta squared $\left(\eta p^{2}\right)$ statistics (SPSS, Statistical Package for Social Sciences, version 11.5).

\section{RESULTS}

A total of 60 children with $\mathrm{CH}$ and 60 healthy children (CG) were assessed. Table 1 shows the relationship profiles of the parents of children with $\mathrm{CH}$ compared to the controls. In terms of relationship with the mother, a statistically significant difference was observed versus the controls in general $(p \leq 0.001)$, with a moderate to high effect size $\left(\eta p^{2}=0.438\right)$.

Specifically, such differences were observed in the control domain: children with $\mathrm{CH}$ perceived a stricter maternal control.

In terms of the relationship of children with $\mathrm{CH}$ and their fathers, it was significantly different from controls in general $(p=0.004)$, with a small effect size. Children with $\mathrm{CH}$ perceived a higher level of paternal acceptance than controls.

Table 2 describes coping strategies. Children with $\mathrm{CH}$ sought more support when dealing with problematic situations and were paralyzed more often than healthy children; differences from the CG were significant (Table 2).

The comprehension subtest of the WISC III was significantly different between groups but with a very small effect size. Children with $\mathrm{CH}$ developed fewer strategies to solve situations that implied a practical social judgment in everyday life (Table 3).

\section{DISCUSSION}

In Argentina, scarce studies have been done aimed at analyzing the impact of $\mathrm{CH}$ as a chronic disease on children and their families. Our purpose was to study the impact of $\mathrm{CH}$ detected in an early manner and treated adequately on parenting styles and coping strategies.

The parent-child relationship is critical in the development of a chronic disease. The ways in which parents react to a disease in one of their children and in which children react in their own setting are varied. Generically, a continuum may be established that goes from hyper-anxiety and excessive indulgence to problems with disease acceptance.

Such set of reactions, centered on the disease, annuls the view of individual development itself, and two opposing parental attitudes should be 
taken into consideration: one where the reaction focuses on disease rejection and one where the child becomes annulled as an individual. Both opposite ends would represent negative poles of the parent-child relationship that would hinder the child's personal growth. ${ }^{11}$
According to our results, children with $\mathrm{CH}$ have a different perception of the maternal relationship from CG children in the control domain, and they perceive a stricter maternal control.

Prior studies have mentioned an increased over-protection or a greater control in the parent-

TABLE 1. Relationship profiles of the parents of children with congenital hypothyroidism and controls

\begin{tabular}{|c|c|c|c|c|c|c|}
\hline \multirow{2}{*}{$\begin{array}{l}\text { Perception of the relationship } \\
\text { with the mother }\end{array}$} & \multicolumn{2}{|c|}{ Children with $\mathrm{CH}(\mathrm{n}=60$} & \multicolumn{2}{|c|}{ Controls $(n=60)$} & \multirow[b]{2}{*}{ F (5.114) } & \multirow[b]{2}{*}{$P$} \\
\hline & Mean & SD & Mean & SDF & & \\
\hline Maternal level of acceptance & 2.42 & 3.3 & 2.47 & 3.5 & 0.430 & 0.513 \\
\hline Acceptable maternal control & 2.30 & 0.36 & 2.30 & 0.35 & 0.002 & 0.966 \\
\hline Strict maternal control & 2.77 & 0.25 & 2.22 & 0.41 & 77.6 & $0.000^{*}$ \\
\hline Pathological maternal control & 1.93 & 0.39 & 1.92 & 0.35 & 0.023 & 0.879 \\
\hline Extreme independence from the mother & 1.56 & 0.43 & 1.69 & 0.43 & 2.64 & 0.107 \\
\hline \multirow{2}{*}{$\begin{array}{l}\text { Perception of the relationship } \\
\text { with the father }\end{array}$} & \multicolumn{2}{|c|}{ Children with $\mathrm{CH}(\mathrm{n}=60)$} & \multicolumn{2}{|c|}{ Controls $(n=60)$} & & \\
\hline & Mean & SD & Mean & SDF & $F(5.114)$ & $P$ \\
\hline Paternal acceptance & 2.44 & 0.31 & 2.21 & 0.28 & 18.86 & $0.000^{*}$ \\
\hline Acceptable paternal control & 2.21 & 0.41 & 2.13 & 0.24 & 1.66 & 0.200 \\
\hline Strict paternal control & 2.12 & 0.38 & 2.07 & 0.45 & 0.517 & 0.474 \\
\hline Pathological paternal control & 2.23 & 0.65 & 2.14 & 0.27 & 0.823 & 0.366 \\
\hline Extreme independence from the father & 2.67 & 0.60 & 2.74 & 0.42 & 0.427 & 0.515 \\
\hline
\end{tabular}

* Adjusted significance level of $\mathrm{p}<0.05$; SD: standard deviation; F: F hypothesis test values; $\mathrm{p}$ : level of significance.

TABLE 2. Coping strategies in children with congenital hypothyroidism and controls

\begin{tabular}{|c|c|c|c|c|c|c|}
\hline \multirow[b]{2}{*}{ Coping strategies } & \multicolumn{2}{|c|}{ Children with $\mathrm{CH}(\mathrm{n}=60)$} & \multicolumn{2}{|c|}{ Controls $(n=60)$} & \multirow[b]{2}{*}{ F (5.114) } & \multirow[b]{2}{*}{$P$} \\
\hline & Mean & SD & Mean & SD & & \\
\hline Logical analysis & 2.21 & 0.41 & 2.36 & 0.43 & 3.45 & 0.065 \\
\hline Cognitive restructuring & 2.50 & 0.42 & 2.51 & 0.43 & 0.20 & 0.888 \\
\hline Cognitive avoidance & 2.20 & 0.50 & 2.04 & 0.51 & 2.80 & 0.097 \\
\hline Seeking support & 2.52 & 0.42 & 2.20 & 0.49 & 15.35 & 0.001 \\
\hline Seeking alternative rewards & 1.98 & 0.44 & 2.24 & 1.05 & 3.10 & 0.080 \\
\hline Emotional control & 1.98 & 0.30 & 2.06 & 0.50 & 1.04 & 0.308 \\
\hline Paralyzation & 1.96 & 0.56 & 1.69 & 0.45 & 8.43 & $0.004^{*}$ \\
\hline Acting on the problem & 2.43 & 0.94 & 2.35 & 0.47 & 0.373 & 0.542 \\
\hline Lack of emotional control & 1.68 & 0.46 & 1.53 & 0.47 & 3.07 & 0.082 \\
\hline
\end{tabular}

* Adjusted significance level of $\mathrm{p}<0.05$; SD: standard deviation; F: F hypothesis test values; $\mathrm{p}$ : level of significance.

TABLE 3. Comprehension subtest (Wechsler Intelligence Scale for Children III) administered to children with congenital hypothyroidism and controls

\begin{tabular}{|c|c|c|c|c|c|c|c|}
\hline \multirow{2}{*}{$\frac{\text { Wechsler }}{\text { Subtest }}$} & \multicolumn{2}{|c|}{ Children with $\mathrm{CH}(n=60)$} & \multicolumn{5}{|c|}{ Controls $(n=60)$} \\
\hline & Mean & SD & Mean & $\mathrm{SD}$ & $\mathrm{t}$ & $\mathrm{p}$ & $\eta p^{2}$ \\
\hline Comprehension & 14.03 & 2.87 & 17.70 & 3.23 & 6.558 & $0.000^{*}$ & 0.01 \\
\hline
\end{tabular}

* Adjusted significance level of $\mathrm{p}<0.05$.

SD: standard deviation; t: Student's t hypothesis test values; p: level of significance. $\eta p^{2}$ : partial Eta squared (effect size). 
child relationship among chronically-ill children. ${ }^{11}$

Although the strict control modality is within the category of a democratic parenting style, it is in the negative end of the "acceptance" factor and was perceived as a less accepted type of control, without being considered a pathological control.

In addition, children with $\mathrm{CH}$ perceived a higher level of acceptance by their fathers (acceptance of their individuation) than controls. This may be due to a greater closeness and indulgence by fathers towards their sick children. Congenital conditions, such as $\mathrm{CH}$, have an impact on parents by thwarting the idealized image they have of their children because chronic diseases are associated with ongoing treatments and medical follow-ups to remind them.

In this condition, the concept of "awareness of a latent disease" becomes increasingly relevant because an adequate follow-up removes the clinical evidence of any potential damage but may not eradicate the fear parents have regarding disease consequences, which results in a stricter control of their children. ${ }^{4}$

The study of coping strategies found that our cohort of children with hypothyroidism had a tendency to seek more support to deal with situations that were difficult to solve and to become paralyzed more often when facing a problem. Such finding is consistent with prior studies that explain the influence of parental coping strategies, which shape less functional strategies in their children. ${ }^{12,13}$ The bibliography points out the importance of making a psychological adjustment among the parents of children with $\mathrm{CH}$ and of their difficulties to cope with their children's disease; this may have a consequence on their children's coping strategies. $3,14,15$

This would explain the lower performance in the comprehension subtest (WISC III) compared to the CG, which assesses the level of strategy development to deal with the situations of daily living. ${ }^{11,12}$

The type of interaction children have with their environment is multifactorial and includes the experiences they have in relation to bonds in their setting, especially primary bonds at an early age that affect their cognitive-behavioral development. . $^{14,15}$

Our results help to establish a relationship between parenting styles and coping strategies in terms of $\mathrm{CH}$. Without being a pathological modality of the parent-child relationship, the perception of a stricter control predisposes to a higher level of dependence and paralysis when dealing with conflicting situations.

Our observations emphasize the importance of recognizing the parent-child interaction in these patients to provide adequate guidance. ${ }^{4,15}$

\section{REFERENCES}

1. OPS. CIE-10. Décima revisión de la Clasificación Internacional de Enfermedades: trastornos mentales y del comportamiento. Madrid: Meditor; 1992.

2. Zimmerman-Tansella C. Factores psicosociales en las enfermedades crónicas en la infancia. In: RodriguezSacristán J (ed.). Psicopatología del niño y del adolescente. 2. da ed. Sevilla: Universidad de Sevilla;1998.Pages.1089-103.

3. Chao MC, Yang P, Hsu H, et al. Follow-up study of behavioural development and parentig stress profiles in children with congenital hypothyroidism. Kaohsiung J Med Sci 2009;25(11):588-95.

4. Chiovato L, Bargagna S. Congenital hypothyroidism: treat children but don't forget their parents. Eur J Endocrinol 1999;14(2):101-4.

5. Lazarus R, Folkman S. Estrés y procesos cognitivos. Barcelona: Martínez Roca; 1986.

6. Richaud de Minzi MC. Evaluación del afrontamiento en niños de 8 a 12 años. Rev Mex Psicol 2006;23(2):193-201.

7. Richaud de Minzi MC. Inventario acerca de la percepción que tienen los niños y niñas de las relaciones con sus padres y madres. Versión para 4-6 años. Rev Interam Psicol 2002;36(1-2):149-65.

8. Richaud de Minzi MC. La percepción de etilos de relación con su padre y madre en niños y niñas de 8 a 12 años. Rev Iberoam Diagn Eval Psicol 2007;23(1):63-81.

9. Ullate Campos A, Guido A, Jiménez K. Estudio sobre calidad de vida de los niños y niñas con Hipotiroidismo Congénito y su familia detectados mediante el Programa Nacional de Tamizaje Neonatal y atendidos en la consulta externa de endocrinología del Hospital Nacional de Niños hasta agosto de2006[Dissertation]. Costa Rica:Universidad de Costa Rica; 2006.

10. Pardo Campos ML, Musso M, Keselman A, et al. Cognitive profiles of patients with early detected and treated congenital hypothyroidism. Arch Argent Pediatr. 2017;115(1):12-7.

11. LuqueParraDJ.Alumnadocon trastorno crónico. Elementos para una intervención psicoeducativa. Rev Iberoam Educ. [Accessed on: September 13 $\left.{ }^{\text {th }}, 2014\right]$. Available at: http: / / rieoei.org / rie_contenedor.php?numero=psi_ edu11\&titulo $=$ Alumnado $\% 2520$ con $\% 2520$ trastorno $\% 2 \overline{5}$ 20cr\%25F3nico.\%2520Elementos\% 2520para\%2520una\% 2520intervenci $\%$ 25F3n\%2520psicoeducativa.

12. Salerno M, Militerni R, Di MaioS, et al. Intellectual outcome at 12 years of age in congenital hypothyroidism. Eur J Endocrinol 1999;141:105-10.

13. Sastre-Riba S. Condiciones temprana del desarrollo y el aprendizaje: el papel de las funciones ejecutivas. Rev Neurol 2006;42(Supl 2):S143-51.

14. Álvarez-GonzálezMA, Caravajal-MartínezF, Pérez-Gesén C, et al. Pronóstico de la cognición en el hipotiroidismo congénito tratado precozmente. Hipótesis del doble efecto. Rev Neurol 2004;38(6):513-7.

15. Boekaerts M, Röder I. Stress, Coping, and adjustment in children with a chronic disease: a review of the literature. Disabil Rehabil 1999;21(7):311-37. 